\title{
HARDSEEDEDNESS OF LOCAL MUNGBEAN (VIGNA RADIATA) VARIETIES
}

\author{
Samanthi K Wasala*1, WDSL Fernando ${ }^{2}$ and IS Narasinghe ${ }^{3}$ \\ ${ }^{1}$ Plant Genetic Resource Centre, Gannoruwa, Peradeniya, Sri Lanka; ${ }^{2}$ Regional Agriculture Research \\ Centre, Makandura (NWP), Sri Lanka; ${ }^{3}$ Seed and Planting Material Division, Bata Ata Seed Farm, Sri Lanka \\ Accepted: 16 December 2010
}

\begin{abstract}
Presence of hard seeds is an inferior character of some mungbean varieties. Hence efforts are made to identify factors affecting hard seed formation and to develop varieties with low percentage of hard seeds. This study aimed to determine the influence of seed size on seed hardness using three recommended local mungbean varieties, MI-5, Harsha and Ari. Seeds were categorized into three size groups; large, medium and small based on seed length and seed weight. MI-5 and Ari consisted with large and medium seeds while Harsha consisted of medium and small seeds. No significant differences of hardseededness were observed between different seed sizes within same variety. Seed hardness of medium seed category of three varieties found to be significantly different to each other. This experiment revealed that there is no significant effect of seed size on hardseededness and the high percentage of hard seeds is associated with variety Harsha is due to inherent character rather than seed size.
\end{abstract}

Key words: Mungbean, Hardseededness, Seed size

\section{INTRODUCTION}

Mungbean is one of the important pulse crops cultivated and consumed in Sri Lanka. Seed quality is one of the important criteria which affect the consumer acceptability of mungbean. Varieties with few hard seeds, large, green seeds with lustre are highly preferred by the consumers. Presence of hard seeds is a major problem especially when it consumed as boiled seeds. Hard seeds are impervious to water and remain hard even after cooking (Argel \& Parton 1999). Lawn et al (1987) observed that seed hardness is high immediately after harvesting and declines with storage to some extent. Further, seed hardness to be controlled by more than one factor. Rodriguez et al. (1990) identified that the occurrence of hard seeds is a physiologically and genetically controlled trait.

MI-5, Ari and Harsha are three mungbean varieties released by the Department of Agriculture, Sri Lanka. Seeds of Harsha are smaller and lighter than other two varieties (Table 1). Harsha has higher rate of hard seeds content than other two varieties. Due to these reasons Harsha has less preference than other two varieties. Present study was conducted to identify the relationship between seed hardness and seed size using three recommended mungbean varieties.

\section{MATERIALS AND METHODS}

The test varieties were grown in the field in 2003 yala season at Filed Crop Research and
Development Institute, Maha Illuppallama under supplementary irrigated conditions. All the cultural practices were done according to the recommendations given by Department of Agriculture. At maturity seeds were harvested, threshed and dried up to $10 \%$ moisture content.

From each variety $500 \mathrm{~g}$ of seeds were used for the experiment. Seed length was measured using Vanier calliper and separated into different categories according to the size (Table1). The percentage of seeds under different groups and 100 seed weight were recorded. From each size category, five replicates consisting of 250 seeds were used to determine hard seed percentages. Seeds were soaked in tap water at room temperature for $4,6,8,10,12 \mathrm{~h}$. After soaking the prescribed period seeds were removed from water and soaked seeds were counted. Soaked seeds are soft and swell while hard seeds remain hard without swelling and softening. Percentages hard seeds were calculated from the total seeds in two hour interval and finally after $12 \mathrm{~h}$.

Pattern of breaking of hard seeds were studied in two hours intervals. Percentage hard seed data were transferred using square root transformation and analysis of variance and mean separation were performed using SAS var. 6.1. Mean separation was done according to the Duncan Multiple Range Test (DMRT).

\section{RESULTS AND DISCUSSION}


Table 1: Criteria used to categorize seeds accordingly to length and 100seed weight, percentages of seeds and hard seeds in each seed category of test varieties

\begin{tabular}{llllll}
\hline Variety & $\begin{array}{l}\text { Seed size } \\
\text { category }\end{array}$ & $\begin{array}{l}\text { Seed } \\
\text { Lenght } \\
(\mathrm{mm})\end{array}$ & $\begin{array}{l}\text { 100 Seed } \\
\text { weight }(\mathrm{g})\end{array}$ & $\begin{array}{l}\% \\
\text { seeds }\end{array}$ & $\begin{array}{l}\text { Hard } \\
\text { seed } \\
\% * *\end{array}$ \\
\hline MI-5 & Medium & 4 to $<5$ & $<5.8$ to $\geq 4.8$ & 22.7 & $1.9 \mathrm{c}^{*}$ \\
& Large & $\geq 5$ & $>5.8$ & 77.3 & $2.1 \mathrm{c}$ \\
Ari & Medium & 4 to $<5$ & $<5.8$ to $\geq 4.8$ & 43.4 & $3.7 \mathrm{~b}$ \\
& Large & $\geq 5$ & $>5.8$ & 56.6 & $3.1 \mathrm{~b}$ \\
Harsha & Small & 3 to $<4$ & $<4.8$ & 22.2 & $9.8 \mathrm{a}$ \\
& Medium & $\geq 5$ & $<5.8$ to $\geq 4.8$ & 77.8 & $7.9 \mathrm{a}$ \\
\hline
\end{tabular}

* means with same letters are not significantly different at $5 \%$ probability level based on DMRT test.

** Seed hardness measured after $12 \mathrm{~h}$ soaking

According to the grouping MI-5 and Ari have large and medium seed categories and Harsha has medium and small seed categories (Table 1). MI-5 and Ari have more large seeds as compared to Harsha with more medium category seeds. Different seed sizes within a plant occur due to differences in sink source ratio and translocation pattern of photosynthetes within a plant (AVRDC 1975).

Percentage hard seeds after $12 \mathrm{~h}$ soaking showed that variety Harsha has significantly high percentage of hard seeds in medium seed category compared to medium seed categories of MI-5 and Ari. Further there was no significant difference observed between percentage hard seeds of small and medium seed categories of Harsha. It was revealed that the occurrence of hard seeds has no relationship with seed size. Pattern of breaking seed hardness in two hour interval showed that it is slower in Harsha as compared to MI-5 and Ari (Fig $1)$.

According to this study variety Harsha showed significantly higher number of hard seeds. This variety inherently has small size seeds as compared to MI-5 and Ari. MI-5 can be identified as inherently low hard seeded variety as compared to Harsha. Argel and Panton (1999) stated that the thickness of the cuticle and the suberization and cutinisation of the malpighia caps has also been associated with the degree of hardseededness.

This study concluded that the occurrence of hard seeds has no relationship with seed size. Therefore, seed size cannot be used as a parameter to separate hardseeds from normal seeds. Further studies are necessary to identify the physiological, genetical and environmental factors effecting hard seed formation.

\section{ACKNOWLEDGMENTS}

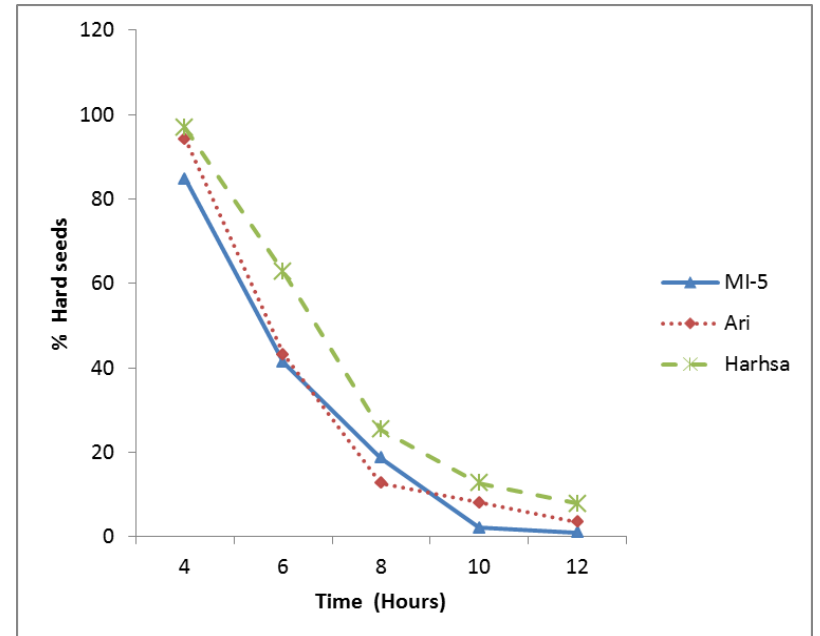

Figure 1. Comparison of breaking seed hardness of tested varieties in two hour soaking intervals

Authors wish to express their gratitude to Ms KDA Perera DD (Research), Mahailluppallma for guidance and encouragements. Assistance given by the staff of the mung bean breeding division is also acknowledged.

\section{REFERENCES}

Argel PJ and Parton CJ 1999 Overcoming legume hardseededness. Forage Seed Production, Volume 2: Tropical and Subtropical Species (eds DS Loch and JE Ferguson) CAB international. 247-259.

AVRDC 1975 Mungbean report for 75: Asian Vegetable Research and Development Centre, Shanhua, Thaiwan 25-29.

Dhirendra K and Singh CB 1992 Factors responsible for hardseededness on Vicia faba L The Indian Journal of Genetics and Plant Breeding. 52( 4): 407-410.

Imrie BC, Rateliff D and Erens JPJ 1987 Analysis of gene action in crosses between early and late maturing mungbean. Mungbean Proceedings of second international Symposium. 145-151.

Imrie BC, Williams RW and Lawn RJ 1987 Breding for resistance to weather damage in mungbean. Mungbean Proceedings of second international Symposium. 130-135.

Lawn RJ, Williams RW and Imrie BC1987 Potential of wild germplasm as a source of tolerance to environmental stress in mung bean. Proceedings of second international Symposium. 136-145.

Rodriguez F M, Mendoza EMT 1990

Physicochemical basis for hardseededness in mung bean (Vigna radiata (L.) Wilczek). J.

Agric. Food Chem., 1990, 38(1): 29-32

Mendoza EMT, Barrag CF, Rodriquez FM, Revilleza J R and Laurena AC 1987 Factors effecting the nutritional quality and acceptability of mungbean (Vigna radiate (L) Wilazek). Ninth 